\title{
Checklist and Scoring System for the Assessment of Soft Tissue Preservation in CT Examinations of Human \\ Mummies: Application to the Tyrolean Iceman \\ Checkliste und Scoringsystem für die Beurteilung des Weichteilerhaltungszustandes anhand von CT Untersuchungen menschlicher Mumien: Anwendung auf Ötzi
}

Authors

Stephanie Panzer ${ }^{1}$, Patrizia Pernter ${ }^{2}$, Dario Piombino-Mascali ${ }^{3}$, Rimantas Jankauskas ${ }^{3}$, Stephanie Zesch ${ }^{4}$, Wilfried Rosendahl ${ }^{4}$, Gerhard Hotz ${ }^{5}$, Albert R. Zink ${ }^{6}$

\section{Affiliations}

1 Department of Radiology, Trauma Center Murnau and Institute of Biomechanics, Trauma Center Murnau and Paracelsus Medical University Salzburg, Murnau, Germany

2 Department of Radiodiagnostics, Central Hospital, Bolzano, Italy

3 Department of Anatomy, Histology and Anthropology, Faculty of Medicine, Vilnius University, Lithuania

4 German Mummy Project, Reiss-Engelhorn-Museen, Mannheim, Germany

5 Anthropology, Natural History Museum of Basel, Switzerland

6 EURAC-Institute for Mummies and the Iceman, Bolzano, Italy

Key words

mummy, computed tomography, checklist, organ

preservation, paleoradiology

received 21.03.2017

accepted 29.06.2017

\section{Bibliography}

DOI https://doi.org/10.1055/s-0043-116668

Published online: 23.8.2017 | Fortschr Röntgenstr 2017; 189:

$1152-1160$

(c) Georg Thieme Verlag KG, Stuttgart · New York

ISSN 1438-9029

\section{Correspondence}

Priv.-Doz. Dr. Stephanie Panzer

Radiologie, Unfallklinik Murnau, Prof.-Küntscher-Strasse 8,

82418 Murnau am Staffelsee, Germany

Tel.: ++ 49/8841/48 4265

Fax: $++49 / 8841 / 482728$

stephanie.panzer@bgu-murnau.de

\section{ZUSAMMENFASSUNG}

Ziel Weichteilgewebe ist die Substanz, die ein Skelett zur Mumie macht und Diagnosen über die Osteologie hinaus erlaubt. Entsprechend dem Ansatz des „structured reporting” in der klinischen Radiologie, wurde eine kürzlich entwickelte Checkliste für die Auswertung der Weichteilerhaltung von Ötzi in der Computertomografie (CT) verwendet. Das Ziel der Studie war, die „CT Checklist and Scoring System for the Assessment of Soft Tissue Preservation in Human Mummies“ bei Ötzi anzuwenden und Ötzis Weichteilerhaltung quantitativ mit den entsprechenden Scores anderer Mumien zu vergleichen.

Material und Methoden Verwendet wurde ein Ganzkörper-CT (SOMATOM Definition Flash, Siemens, Forchheim, Germany) bestehend aus fünf Scans, das im Januar 2013 in der Abteilung für Radiodiagnostik, Zentralkrankenhaus Bozen durchgeführt wurde (Schichtdicke 0,6 mm; Spannung von 80 bis 140 Kilovolt). Die standardisierte Auswertung erfolgte anhand der "CT Checklist and Scoring System for the Assessment of Soft Tissue Preservation in Human Mummies".

Ergebnisse Aus der Hauptkategorie "A. Soft Tissues of Head and Musculoskeletal System" waren alle Checkpoints erhalten, aus der Hauptkategorie "B. Organs and Organ Systems" mehr als die Hälfte. Das Scoringsystem ergab einen Gesamtscore von 153 (von 200). Der Vergleich der Scores von Ötzi und drei Mumiensammlungen aus Vilnius, Litauen und Palermo, Sizilien sowie einer Einzelmumie aus Ägypten ergab überwiegend höhere Scores der Weichteilerhaltung bei Ötzi. Schlussfolgerung Die Anwendung der Checkliste ermöglichte eine standardisierte Beurteilung und Dokumentation von Ötzis Weichteilerhaltung. Das Scoringsystem erlaubte einen quantitativen Vergleich zwischen Ötzi und anderen Mumien. Ötzi zeigte eine ausgezeichnete Weichteilerhaltung.

\section{Kernaussagen}

- Der Ansatz des “structured reporting” kann auf die Paläoradiologie übertragen werden.

- Die Checkliste ermöglichte eine standardisierte Beurteilung und Dokumentation der Weichteilerhaltung. 
- Das Scoringsystem ermöglichte einen quantitativen Vergleich zwischen Mumien.

- Ötzi hat eine ausgezeichnete Weichteilerhaltung im CT.

\section{ABSTRACT}

Purpose Soft tissues make a skeleton into a mummy and they allow for a diagnosis beyond osteology. Following the approach of structured reporting in clinical radiology, a recently developed checklist was used to evaluate the soft tissue preservation status of the Tyrolean Iceman using computed tomography (CT). The purpose of this study was to apply the "Checklist and Scoring System for the Assessment of Soft Tissue Preservation in CT Examinations of Human Mummies" to the Tyrolean Iceman, and to compare the Iceman's soft tissue preservation score to the scores calculated for other mummies.

Materials and Methods A whole-body (CT) (SOMATOM Definition Flash, Siemens, Forchheim, Germany) consisting of five scans, performed in January 2013 in the Department of Radiodiagnostics, Central Hospital, Bolzano, was used (slice thickness $0.6 \mathrm{~mm}$; kilovolt ranging from 80 to 140). For standardized evaluation the " $\mathrm{CT}$ Checklist and Scoring System for the Assessment of Soft Tissue Preservation in Human Mummies" was used.

Results All checkpoints under category "A. Soft Tissues of Head and Musculoskeletal System" and more than half in category "B. Organs and Organ Systems" were observed. The scoring system accounted for a total score of 153 (out of 200). The comparison of the scores between the Iceman and three mummy collections from Vilnius, Lithuania, and Palermo, Sicily, as well as one Egyptian mummy resulted in overall higher soft tissue preservation scores for the Iceman.

Conclusion Application of the checklist allowed for standardized assessment and documentation of the Iceman's soft tissue preservation status. The scoring system allowed for a quantitative comparison between the Iceman and other mummies. The Iceman showed remarkable soft tissue preservation.

\section{Key Points}

- The approach of structured reporting can be transferred to paleoradiology.

- The checklist allowed for standardized soft tissue assessment and documentation.

- The scoring system facilitated a quantitative comparison among mummies.

- Based on CT, the Tyrolean Iceman demonstrated remarkable soft tissue preservation.

\section{Citation Format}

- Panzer S, Pernter P, Piombino-Mascali D et al. Checklist and Scoring System for the Assessment of Soft Tissue Preservation in CT Examinations of Human Mummies: Application to the Tyrolean Iceman. Fortschr Röntgenstr 2017; 189: $1152-1160$

\section{Introduction}

The first computed tomography (CT) examination of an Egyptian mummy was reported in 1979 [1]. Since then, CT has developed into the "gold standard" of imaging modalities for paleopathological studies due to its non-destructive nature, high spatial resolution, image contrast, and the possibility of different post-processing modalities. Today, CT is an essential resource within the multidisciplinary scientific study of mummies [2 - 8].

Soft tissues differentiate a skeleton from a mummy, and they allow diagnosis beyond osteology [9]. In contrast to bones, soft tissues undergo a distinct post-mortem change during the mummification process, mainly due to tissue dehydration [9]. Soft tissues are known to have a different appearance on CT images compared to those taken from living patients with regard to density, size and shape, and sometimes location within the body. Therefore, correct image interpretation is often challenging [10 - 15].

Since his discovery 25 years ago, the Tyrolean Iceman has undergone several CT examinations. The first detailed radiological description was published in 2003 [16] and included the evaluation of CT examinations undertaken between September 1991 and June 2001, with a slice thickness ranging from 1 to $8 \mathrm{~mm}$. In addition to a detailed description of the preservation of bony and soft tissues, the authors documented anatomical variants, evidence of skeletal damage due to the glacial environment and also as a result of the recovery effort, evidence of health-related conditions, as well as his adaption to the environment. Other studies based on CT examinations have dealt with probable postmortem changes of the periarticular bone regions [17]; the body size, body proportions and mobility of the Tyrolean Iceman [18]; oral pathology [19] and his cause of death [20, 21]. In 2011, new radiological insights into the life and death of the Iceman were published [12], presenting new findings such as three gallbladder stones, enthesopathies of the knees, and taphonomic changes in the form of radio-opaque objects superficially embedded within the soft tissues. Furthermore, the stomach, which had always been assumed to be empty, could be exactly identified and was found to be well filled, shedding new light on the scenario leading to his violent death [12]. The subsequent sampling of the Iceman's stomach contents through an incision identified a 5300-year-old Helicobacter pylori genome [22].

In this study, a recently developed "Checklist and Scoring System for the Assessment of Soft Tissue Preservation in CT Examinations of Human Mummies" [10] was applied to CT examinations of the Tyrolean Iceman. In the field of paleopathology, the need for standardization has been expressed for many years. The checklist was developed following the approach of structured reporting, which is increasingly being established in clinical radiology [23-25]. The checklist serves as a tool to guide the radiologist through the main soft tissue structures throughout the body and allows standardized checkpoint acquisition. The additional scor- 
ing system allows quantitative comparison of the soft tissue preservation status of individual mummies or mummy collections.

The aim of this study was to assess and document the soft tissue preservation of the Tyrolean Iceman by applying the checklist. The second aim was to evaluate the additional scoring system to quantitatively compare the Iceman's soft tissue preservation score to corresponding scores of other mummies and mummy collections.

\section{Materials and Methods}

\section{Materials}

For the evaluation of the Iceman's soft tissue preservation, a whole-body CT (SOMATOM Definition Flash, Siemens, Forchheim, Germany) performed in January 2013 in the Department of Radiodiagnostics of the Central Hospital of Bolzano was used (permission was given by the South Tyrol Museum of Archaeology, Bolzano, Italy). As a result of the complicated posture of the Iceman due to the outstretched left arm ( $>$ Fig. 1), the CT examination consisted of five scans (head, total body from head to feet, head to upper abdomen in left oblique position, upper extremities, lower extremities from pelvis to feet), all performed with a slice thickness of $0.6 \mathrm{~mm}$, and 100 and 120 kilovolt (kV) (additional dual energy technique with $80 / 140$ and $100 / 140 \mathrm{kV}$ ) in bone and standard algorithm. For the comparison of the Iceman's soft tissue preservation to other mummies, the following data were used:

- A collection of 7 mummies from the crypt of the Dominican Church of the Holy Spirit of Vilnius, Lithuania, tentatively dating from the $18^{\text {th }}$ and $19^{\text {th }}$ centuries AD. All mummies were spontaneously mummified. The mummies were examined by whole-body CT (Mx8000 Dual, Philips, Best, The Netherlands) with a slice thickness of $1.3 \mathrm{~mm}$ and $120 \mathrm{kV}$ in standard algorithm (data from the "Lithuanian Mummy Project", partially published in [10, $26-28])$.

- A collection of 6 spontaneously mummified bodies from the Capuchin Catacombs of Palermo, Sicily, dating from the late $18^{\text {th }}$ to the late $19^{\text {th }}$ centuries AD. The mummies were examined using a mobile CT scanner (Alliance Medical, Warwick, UK; LightSpeed Plus, GE Healthcare, Milwaukee, Wisconsin, USA). Whole-body CT examinations were performed with a slice thickness of $1.25 \mathrm{~mm}$ and $120 \mathrm{kV}$ in standard algorithm (data from the "Sicily Mummy Project", partially published in $[10,29])$.

- A collection of seventeen anthropogenically preserved mummies from the same crypt in Palermo that were also studied by CT as described above.

- A spontaneously mummified Egyptian mummy dating from the Old Kingdom (2686 to 2160 BC [30]). The mummy was examined by whole-body CT (Emotion 16, Siemens, Forchheim, Germany) with a slice thickness of $0.75 \mathrm{~mm}$ and $130 \mathrm{kV}$ in standard algorithm (own data).

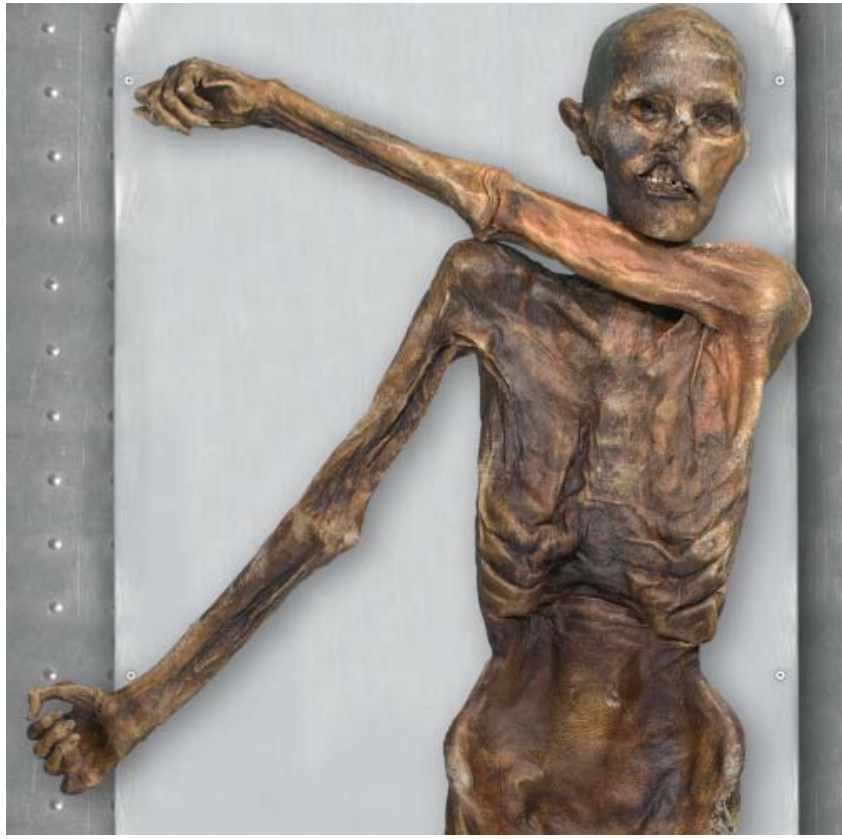

- Fig. 1 Photograph of the Tyrolean Iceman mummy in his preservation cell at the South Tyrol Museum of Archaeology in Bolzano, Italy. The mummy is kept at minus $6-7^{\circ}$ Celsius under ambient conditions.

- Abb. 1 Fotografie der Mumie von Ötzi in seiner Konservierungszelle im Südtiroler Archäologiemuseum in Bozen, Italien. Die Mumie wird in Raumluft bei $6-7^{\circ}$ Celsius aufbewahrt. Quelle: EURAC.

\section{Methods}

The recently developed "Checklist and Scoring System for the Assessment of Soft Tissue Preservation in CT Examinations of Human Mummies" [10] was used for the assessment. The checklist contains 97 checkpoints and is divided into two main categories: "A. Soft Tissues of Head and Musculoskeletal System" and "B. Organs and Organ Systems". As suggested, each checkpoint was scored "present $(+)$ " when at least any part of the structure was detectable, or "absent (-)" when the anatomical structure was not detectable at all.

For the calculation of the scores, the values of the detectable checkpoints were added to the various subcategories and the two main categories, as well as for the total score.

The scores of the Tyrolean Iceman were compared to the scores of the mummy collections from Vilnius and Palermo (given as a mean) and of the Egyptian mummy.

Radiological evaluation and performance of multi-planar reconstructions were carried out using the Picture Archiving and Communicating System (ImpaxEE, Agfa HealthCare, Bonn, Germany). Application of the checklist to CT examinations of all studied mummies was performed by the first author who is a senior radiologist with 19 years of experience in clinical radiology and 14 years of experience in paleoradiology. 
- Table 1 The completed checklist and the calculated scores for the soft tissue preservation status of the Tyrolean Iceman. For calculation of the scores, the values of the detectable checkpoints were added at the level of the various subcategories and the two main categories, as well as for the total score. Values of checkpoints that were not present in the Iceman are shown in brackets.

- Tab. 1 Die ausgefüllte Checkliste und die errechneten Scores für Ötzis Weichteilerhaltung. Für die Berechnung der Scores wurden die Werte für jeden erkennbaren Checkpoint auf dem Level der verschiedenen Subkategorien, der beiden Hauptkategorien und des Gesamtscores addiert. Werte von nicht vorhandenen Checkpoints sind in Klammern gesetzt.

\begin{tabular}{|c|c|c|c|c|c|}
\hline checkpoints & $\mathbf{x}$ & score & checkpoints & $\mathbf{x}$ & score \\
\hline $\begin{array}{l}\text { A. soft tissues of head and musculoskeletal } \\
\text { system }\end{array}$ & & 100 & B. organs and organ systems & & 53 \\
\hline A.1. head & & 20 & $\begin{array}{l}\text { B.1. central nervous system and } \\
\text { peripheral nerves }\end{array}$ & & 10 \\
\hline nose & + & 4 & brain mass/fragments & - & $(1)$ \\
\hline auricle right & + & 2 & or & & \\
\hline auricle left & + & 2 & brain cerebrum & + & 2 \\
\hline ossicles right & + & 1 & brain cerebellum & + & 1 \\
\hline ossicles left & + & 1 & brain brainstem & + & 1 \\
\hline bulb and/or lens right & + & 1 & trigeminal and/or facial nerve & + & 1 \\
\hline optic nerve right & + & 1 & spinal cord and/or dura cervical & + & 1 \\
\hline eye muscles right & + & 1 & spinal cord and/or dura thoracic & + & 1 \\
\hline bulb and/or lens left & + & 1 & peripheral nerves cervical & + & 1 \\
\hline optic nerve left & + & 1 & peripheral nerves thoracic & + & 1 \\
\hline eye muscles left & + & 1 & peripheral nerves lumbar & + & 0.5 \\
\hline falx & + & 2 & peripheral nerves sacral & + & 0.5 \\
\hline tentorium & + & 2 & B.2. cardiorespiratory system & & 12 \\
\hline A.2. musculoskeletal system & & 80 & hypopharynx and/or larynx & + & 1 \\
\hline A.2.1. tendons and/or musculature & & 40 & thyroid gland & - & $(5)$ \\
\hline neck and trunk & & & trachea & + & 2 \\
\hline skull-base & + & 4 & lung right & + & 2.5 \\
\hline neck & + & 4 & lung left & + & 2.5 \\
\hline thoracic and/or lumbar spine & + & 4 & heart pericardium & + & 1 \\
\hline pelvis & + & 4 & heart intraventricular septum & - & $(1)$ \\
\hline extremities & & & heart four chambers & - & $(1)$ \\
\hline upper arm right & + & 2 & heart myocardium & + & 1 \\
\hline upper arm left & + & 2 & heart valves & - & (1) \\
\hline forearm right & + & 2 & diaphragm right & + & 1 \\
\hline forearm left & + & 2 & diaphragm left & + & 1 \\
\hline hand right & + & 2 & B.3. gastrointestinal system & & 25 \\
\hline hand left & + & 2 & tongue & + & 5 \\
\hline thigh right & + & 2 & esophagus & - & (5) \\
\hline thigh left & + & 2 & stomach & + & 2.5 \\
\hline lower leg right & + & 2 & intestine & + & 5 \\
\hline lower leg left & + & 2 & rectum and/or anus & + & 2.5 \\
\hline foot right & + & 2 & liver & + & 5 \\
\hline foot left & + & 2 & gallbladder & + & 5 \\
\hline A.2.2. peri- and intra-articular soft tissues & & 32 & spleen & - & $(5)$ \\
\hline shoulder right rotator cuff & + & 2 & pancreas & - & $(5)$ \\
\hline shoulder right long biceps tendon & + & 2 & B.4. genitourinary system & & 5 \\
\hline
\end{tabular}


- Table 1 (Continuation)

\begin{tabular}{|c|c|c|c|c|c|}
\hline checkpoints & $\mathbf{x}$ & score & checkpoints & $\mathbf{x}$ & score \\
\hline shoulder right capsule and/or labrum & + & 2 & kidney right & - & $(2.5)$ \\
\hline shoulder left rotator cuff & + & 2 & kidney left & - & $(2.5)$ \\
\hline shoulder left long biceps tendon & + & 2 & urinary bladder & - & (5) \\
\hline shoulder left capsule and/or labrum & + & 2 & prostate & - & (5) \\
\hline hip right capsule and/or labrum & + & 4 & or & & \\
\hline hip left capsule and/or labrum & + & 4 & uterus & - & (5) \\
\hline knee right anterior cruciate ligament & + & 1.5 & external genitals penis & + & 2.5 \\
\hline knee right posterior cruciate ligament & + & 1.5 & external genitals scrotum & + & 2.5 \\
\hline knee right medial meniscus & + & 1.5 & or & . & \\
\hline knee right lateral meniscus & + & 1.5 & external genitals labia & - & (5) \\
\hline knee left anterior cruciate ligament & + & 1.5 & B.5. vasculature-arteries & & 1 \\
\hline knee left posterior cruciate ligament & + & 1.5 & intracranial carotid arteries & + & 1 \\
\hline knee left medial meniscus & + & 1.5 & cervical carotid arteries & - & (1) \\
\hline knee left lateral meniscus & + & 1.5 & mediastinal/thoracic arteries & - & (1) \\
\hline A.2.3. intervertebral discs & & 8 & coronary arteries & - & (1) \\
\hline thoracic spine & + & 4 & abdominal aorta & - & (1) \\
\hline \multirow[t]{5}{*}{ lumbar spine } & + & 4 & pelvic arteries & - & (1) \\
\hline & & & thigh arteries right & - & (1) \\
\hline & & & lower leg arteries right & - & (1) \\
\hline & & & thigh arteries left & - & (1) \\
\hline & & & lower leg arteries left & - & (1) \\
\hline
\end{tabular}

\section{Results}

\section{Checklist}

On the CT images of the Tyrolean Iceman, 74 out of the total 97 checkpoints were present ( $\vee$ Table 1 ). All checkpoints of the main category "A. Soft Tissues of Head and Musculoskeletal System" were detectable including the subcategories "A.1. Head," "A.2.1. Tendons and/or Musculature" at different regions of the body, "A.2.2. Peri- and Intra-articular Soft Tissues" of the shoulders, hips and knees ( $\triangleright$ Fig. 2), and "A.2.3. Intervertebral Discs". Slightly more than half of the checkpoints in the main category "B. Organs and Organ Systems" were present. These included all checkpoints of the subcategory "B.1. Central Nervous System and Peripheral Nerves" ( $\triangleright$ Fig. 3). More than half of the checkpoints in the subcategories "B.2. Cardiorespiratory System" and "B.3. Gastrointestinal System” ( $\triangleright$ Fig. 4) were detectable. In the subcategory "B.4. Genitourinary System" only the external genitals were preserved and in the subcategory "B.5. Vasculature-Arteries" only the intracranial carotid arteries were found. Apart from the checklist, preservation of the optic chiasm and the pituitary gland was conspicuous.

\section{Scoring System}

The scoring system accounted for a total score of the Iceman's soft tissue preservation of 153 (out of 200). The total score consisted of 100 (out of 100) for main category A, and 53 (out of 100) for main category B ( $\triangleright$ Table 1 ).

The comparison of the scores between the Tyrolean Iceman and three mummy collections from Vilnius and Palermo as well as one Egyptian mummy resulted in overall higher soft tissue preservation scores for the Iceman ( $\triangleright$ Table 2 ). The Iceman's total score of 153 was higher than all other total scores. Also, the scores for main category $A$ and all subcategories of $A$ were higher compared to the other mummies. The score of main category $B$ was the same as the mean value of the anthropogenic mummies from Palermo; the other mummies had lower scores. In main category $\mathrm{B}$, the collection of mummies from Vilnius and the collection of anthropogenic mummies from Palermo had higher scores for subcategory "B.4. Genitourinary System”. The Egyptian mummy achieved higher scores for subcategory "B.2. Cardiorespiratory System". Compared to the Iceman, the collections from Vilnius and Palermo had higher scores for subcategory "B.5. Vasculature-Arteries". 

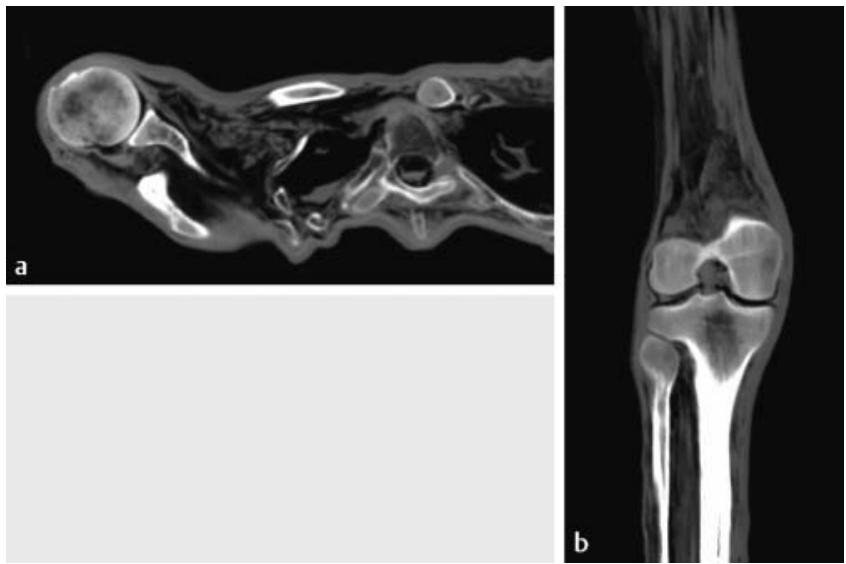

> Fig. 2a Paraaxial multiplanar reconstruction of the right shoulder illustrating preserved anterior and posterior labrum, and subscapularis and infraspinatus tendons and muscles. Note the preserved spinal cord of the thoracic spine and the remnants of collapsed lungs on both sides. $\mathbf{b}$ Coronal multiplanar reconstruction of the right knee showing preservation of the anterior and posterior cruciate ligaments and the medial and lateral meniscus. Note the preservation of tendons and musculature of the adjacent thigh and lower leg.

- Abb. 2a Paraaxiale multiplanare Rekonstruktion der rechten Schulter mit Darstellung des erhaltenen anterioren und posterioren Labrums sowie der Sehnen und Muskelbäuche des M. subscapularis und infraspinatus. Zu beachten sind das erhaltene Rückenmark in Höhe der Brustwirbelsäule und die Reste der kollabierten Lunge auf beiden Seiten. b Koronare multiplanare Rekonstruktion des rechten Kniegelenkes mit Darstellung des vorderen und hinteren Kreuzbandes sowie des Innen- und Außenmeniskus. Zu beachten sind die erhaltenen Sehnen und die Muskulatur im angrenzenden Ober- und Unterschenkel.

\section{Discussion}

In this study, the "Checklist and Scoring System for the Assessment of Soft Tissue Preservation in CT Examinations of Human Mummies" was applied to a whole-body CT examination of the Tyrolean Iceman. The checklist allowed standardized assessment and documentation of the soft tissues and the scoring system enabled comparison with one other mummy and three mummy collections.

Based on the checklist, the $\mathrm{CT}$ images revealed a consistently high preservation of the soft tissues of the head and musculoskeletal system, whereas the preservation of the soft tissues of the organs and organ systems varied to a high degree. It is known that mummification can differ within one individual due to variations within the composition of individual soft tissues and can also vary with regard to the time required for the mummification of different body parts [31]. From a review of paleopathological cases and the literature, it appears that the soft tissues of the musculoskeletal system are better preserved than organs $[6,9]$. One explanation by Lynnerup [6] is that "the larger the ratio of skin surface is to the underlying body volume, the more water can be evaporated from the body segments in question. This means that fingers and toes, and the extremities to a lesser degree, will often show more pronounced mummification than the trunk". In the Tyrolean Iceman, a high degree of preservation of
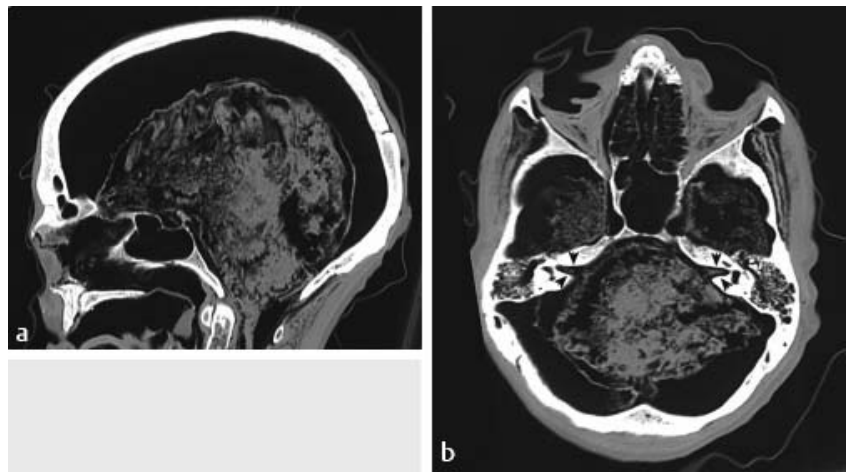

- Fig. 3a Sagittal multiplanar reconstruction of the head demonstrating the moderately shrunken brain with discernible cerebrum, cerebellum, brainstem, hindbrain, and spinal cord of the upper cervical spine. Note the soft tissue preservation of the flattened nose. b Paraaxial multiplanar reconstruction of the skull-base illustrating preserved parts of the facial and vestibulochochlear nerve on both sides, with detectable structures in their extra- and intrameatal course (arrows). Especially on the left side, the facial nerve (anterior) and the vestibulocochlear nerve (posterior) are discernible in the extrameatal course. Note the partial preservation of the tentorium, preservation of intraorbital soft tissues (eye bulb and muscles), and tendons/musculature of the skull-base in the temporal region.

- Abb. 3a Sagittale multiplanare Rekonstruktion des Kopfes mit Illustration des mäßig geschrumpften Hirns, wobei Cerebrum, Cerebellum, Hirnstamm, Medulla oblongata und das Rückenmark in Höhe der oberen Halswirbelsäule erkennbar sind. Zu beachten ist die Erhaltung des Weichteils der abgeflachten Nase. b Paraaxiale multiplanare Rekonstruktion der Schädelbasis mit beidseitiger Darstellung von erhaltenen Anteilen des Nervus facialis und Nervus vestibulocochlearis, wobei Strukturen im extra- und intrameatalen Verlauf (Pfeile) zu sehen sind. Vor allem auf der linken Seite sind der Nervus facialis (anterior) und der Nervus vestibulocochlearis (posterior) im extrameatalen Verlauf zu differenzieren. Zu beachten ist die Erhaltung des Tentoriums, intraorbitaler Weichteile (Augenbulbus und -muskeln) sowie der Sehnen/Muskulatur der Schädelbasis in der Temporalregion.

the soft tissues of the musculoskeletal system was present not only at the level of the extremities, but also in the neck and trunk.

In organs and organ systems, the highest preservation was found in the soft tissues of the central nervous system and peripheral nerves. The brain was preserved in detail. However, as known for most mummies, differentiation between grey and white matter was not possible on the CT images. As already reported by Murphy et al. [16], the shrinkage of the brain was not as severe as that of other soft tissues. To explain this relative preservation of brain volume, the authors assumed that the skull created a microenvironment for the brain that differed from the general environment to which the rest of the body was exposed. Murphy et al. [16] reported that the peripheral nerves were never identified. However, this study highlighted the preservation of the facial nerve (seventh cranial nerve) and the vestibulocochlear nerve (eighth cranial nerve), as well as preservation of several spinal nerves of the entire spine.

With regard to the cardiorespiratory system, most landmarks were present, except for the thyroid gland and details of the heart, such as the intraventricular septum, the four chambers, 


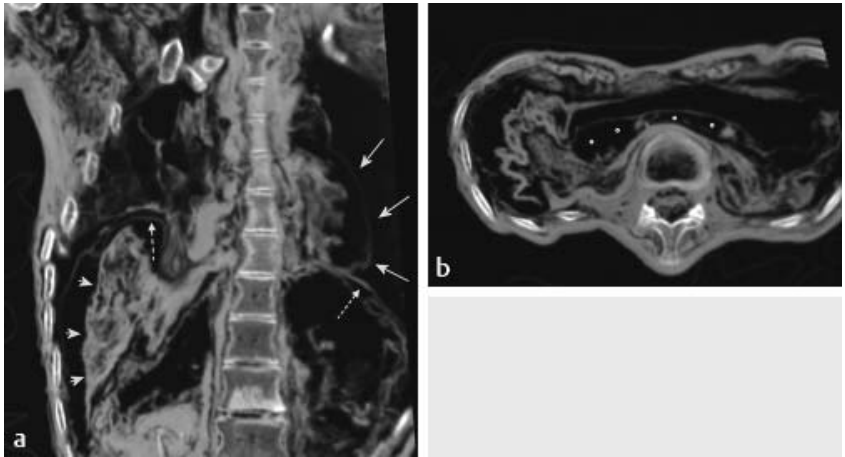

- Fig. 4a Coronal multiplanar reconstruction of the chest and upper abdomen illustrating parts of the preserved pericardium (arrows) close to the left diaphragm (dotted arrow), preservation of the right diaphragm (dotted arrow), and the liver (short arrows). Note the collapsed lung parenchyma on the right side. b Axial multiplanar reconstruction of the upper abdomen showing the stomach (circles) after evacuation with small remnants of food. Note the preservation of the spinal cord and the tendons/musculature of the thoracic spine.

- Abb. 4a Koronare multiplanare Rekonstruktion von Thorax und Oberbauch mit Darstellung von Teilen des erhaltenen Perikards (Pfeile) in enger Lagebeziehung zum linken Zwerchfell (gestrichelter Pfeil), des erhaltenen rechten Zwerchfells (gestrichelter Pfeil) und der Leber (kurze Pfeile). Zu beachten ist das kollabierte Lungenparenchym auf der rechten Seite. b Axiale multiplanare Rekonstruktion des Oberbauches mit Illustration des Magens (Kreise) nach Entleerung mit kleineren Nahrungsresten. Zu beachten ist die Erhaltung des Rückenmarks und der Sehnen/Muskulatur der Brustwirbelsäule.

and the heart valves. In their publication, Murphy et al. described that the heart and large vessels were identified as a flat, thin structure sandwiched between the sternum and the thoracic spine. In our study, we found parts of the pericardium and myocardium almost in the correct anatomical position with close relation to the left diaphragm.

From the gastrointestinal and genitourinary systems, the only preserved parenchymatous organ was the liver. Preserved structures of the gallbladder could be identified by means of the already described gallstones [12]. The stomach and intestine were discernible in accordance with the descriptions of Gostner et al. [12].

The only evidence of the arteries was the intracranial carotid arteries. Murphy et al. [16] have already described several calcifications in areas where arteries would normally be located, including both carotid arteries at the level of the sella turcica, the left carotid artery in the neck, the distal aorta and the right iliac artery. However, calcification without detectable wall structure of the vessel cannot account for the presence of the arteries following the definitions of the checklist [10]. Murphy et al. [16] stated that the arteries themselves could not be identified because of mummification and distortion. However, the fact that almost all of the checkpoints for the arteries were not present might be due to the limitations regarding the identifiability of these arteries on CT images rather than to the lack of preservation. With regard to the Iceman's cause of death, the left subclavian artery showed a laceration of the dorsal wall with subsequent development of a pseudoaneurysm [21]. In addition, the intact left subclavian vein as well as the right subclavian artery and vein could be identified [21]. This means that the presetting of the checklist has led to the rather poor results for assessing the preservation of arteries in the Iceman. The authors have already mentioned that the noninvasive radiological assessment of blood vessels in mummies is problematic. They stated that the apparent lack of intravascular blood and the lack of livor mortis in the Iceman correspond well with the diagnosis of injury-related peri-mortem exsanguination.

In mummies that are not fully examined or assessed on several occasions such as the Tyrolean Iceman, the systematic and standardized identification and assessment of soft tissues on CT is considered the starting point for the detection of possible pathological findings in those tissues.

Based on the scoring system, the Iceman showed higher soft tissue preservation compared to other mummies. This fact indicates that the spontaneous mummification by freeze-drying was very effective for the Iceman for more than 5000 years. Except for the Egyptian mummy, the compared mummies had higher scores for the arteries, which were apparently more detectable than in the Iceman, as mentioned above. The collection of the spontaneous Vilnius mummies had higher mean scores for the genitourinary system due to preservation of the kidneys and the urinary bladder in some cases, and even the uterus in one case. The anthropogenic mummies of Palermo also revealed higher mean scores for the genitourinary system, due to the preservation of the kidneys and urinary bladder in some cases and the prostate in one case. It should be mentioned that 8 out of these 17 anthropogenic mummies had higher total scores than the Iceman with a maximum score of 189 in the best-preserved mummy. However, these mummies were all carefully treated shortly after death, for example by means of intra-arterial injection of chemicals, such as arsenic and mercury [10, 32]. The Egyptian mummy from the Old Kingdom was the oldest mummy with available CT data for this study. In contrast to the Iceman, this mummy showed better preservation of the heart with an additionally detectable intraventricular septum, four chambers, and heart valves. Quantitative comparison of the soft tissue preservation of mummies could contribute to a better understanding of the taphonomy of mummification. Taphonomy describes the effects of postmortem processes that alter the decay mechanism sufficiently to result in mummification [9]. In spontaneous mummies, differences in the quality of mummification are mainly attributed to environmental conditions, such as cold temperatures and hot and arid climates. In anthropogenic mummies, additional postmortem manipulations (e. g. arterial injection, organ removal or packing of the body cavities) might lead to high-quality mummification. In future studies, the checklist and scoring system will be applied to mummies and mummy collections from different time periods and geographic origins to establish a database in order to allow comparative analyses of different types of mummies. Thus, for example, it would be possible to understand the kind of mummies in which preservation of certain inner organs, such as the heart, liver or pancreas could be detected, and what kind of anthropogenic methods caused it. During the interpretation of the radiological findings, the cultural background of the mummified individual also needs to be considered, as this could influence the preservation of specific organs or soft tissues. For example, the 
- Table 2 Comparison of the total scores and scores of the main categories and subcategories of the Tyrolean Iceman with those of mummy collections from Vilnius and Palermo and of a single mummy from Egypt.

- Tab. 2 Vergleich des Gesamtscores sowie der Scores der Haupt- und Subkategorien von Ötzi und Mumiensammlungen aus Vilnius und Palermo sowie einer Mumie aus Ägypten.

\begin{tabular}{|c|c|c|c|c|c|}
\hline & $\begin{array}{l}\text { Tyrolean Iceman (sm) } \\
3350-3100 \mathrm{BC}\end{array}$ & $\begin{array}{l}\text { Vilnius }(n=7, s m) \\
18^{\text {th }}-19^{\text {th }} \text { centuries AD }\end{array}$ & $\begin{array}{l}\text { Palermo }(n=6, s m) \\
18^{\text {th }}-19^{\text {th }} \text { centuries AD }\end{array}$ & $\begin{array}{l}\text { Palermo }(n=17, \text { am }) \\
18^{\text {th }}-19^{\text {th }} \text { centuries AD }\end{array}$ & $\begin{array}{l}\text { Egypt (sm) } 3 \text { rd } \\
\text { millennium BC }\end{array}$ \\
\hline A. & 100 & $84^{*}$ & $67^{*}$ & $89^{*}$ & 76 \\
\hline A. 1 . & 20 & $11^{*}$ & $13^{*}$ & $17^{*}$ & 8 \\
\hline A.2.1. & 40 & $38^{*}$ & $32^{*}$ & $35^{*}$ & 38 \\
\hline A.2.2. & 32 & $29^{*}$ & $19^{*}$ & $29^{*}$ & 22 \\
\hline A.2.3. & 8 & $6^{*}$ & $3^{*}$ & $8^{*}$ & 8 \\
\hline B. & 53 & $47^{*}$ & $28^{*}$ & $53^{*}$ & 41.5 \\
\hline B.1. & 10 & $5^{*}$ & $3^{*}$ & $8^{*}$ & 5 \\
\hline B.2. & 12 & $12^{*}$ & $7^{*}$ & $10^{*}$ & 13 \\
\hline B.3. & 25 & $15^{*}$ & $10^{*}$ & $19^{*}$ & 17.5 \\
\hline B.4. & 5 & $10^{*}$ & $5^{*}$ & $11^{*}$ & 5 \\
\hline B.5. & 1 & $5^{*}$ & $3^{*}$ & $6^{*}$ & 1 \\
\hline total & 153 & $131^{*}$ & $95^{*}$ & $143^{*}$ & 117.5 \\
\hline
\end{tabular}

sm: spontaneous mummification. am: anthropogenic mummification. * : given as a mean. Scores that were higher in other mummies than in the Iceman are highlighted.

sm: natürliche Mumifikation. am: anthropogene Mumifikation. * : als Mittelwert angegeben. Scores, die bei den anderen Mumien im Vergleich zu Ötzi höher waren, sind hervorgehoben.

removal of the brain and inner organs, such as the stomach and intestines, was a common practice in ancient Egyptian embalming [33]. Application of the checklist to CT examinations with variable technical parameters is not regarded as a relevant limitation. The checklist was developed by means of examinations with a slice thickness and interval of 1.25 and $1.3 \mathrm{~mm}$, respectively. Therefore, a thinner slice thickness is not required. For assessing the Iceman, we used mainly multiplanar reconstructions with a slice thickness of $1.25 \mathrm{~mm}$. Thicker slices of 2.5 or $3 \mathrm{~mm}$ should be sufficient for evaluating the main soft tissue structures. However, assessment of intraorbital structures and intracranial and spinal nerves might be difficult in some cases. So far, there is no gold standard for "how to perform a CT scan of a mummy". Nowadays, most CT examinations of mummies are performed similarly to a multiple trauma $C T$ in the clinical setting with acquisition of volume data allowing reconstructions with any desired slice thickness and algorithm.

The current version of the checklist was regarded as a "living document" that might be revised following further iterative steps and could be adapted to special demands in future mummy studies [10]. Based on the checklist, the Iceman was not a "perfect" mummy, as some organs and organ systems were not present. However, the intracranial structures, such as the optic chiasm and the pituitary gland were preserved in detail. Apparently, both structures were not conspicuous in any of the mummies from Vilnius or Palermo (which have been used for developing the checklist), and therefore were not included as a checkpoint. In a future revision of the checklist, these should be included.

Some limitations of the study should also be considered. These consist of the difficulties highlighted in the "Checklist and Scoring System" as mentioned in the publication [10]. This includes the selection of checkpoints, which is based on the experience and specialism of the authors, and the fact that the scoring system may be subjective to some extent. Furthermore, the definition of checkpoints as "present" or "absent" does not acknowledge the degree of preservation of the respective soft tissue structures.

\section{Conclusion}

The application of the "Checklist and Scoring System" to wholebody CT of the Tyrolean Iceman has allowed for standardized assessment and documentation of soft tissue preservation. The scoring system facilitated a quantitative comparison between the soft tissue preservation of the Iceman and other mummies, with the Iceman demonstrating higher soft tissue preservation. The results are in accordance with the current radiological knowledge concerning the Iceman. Detection of details, such as the facial nerve, and interpretation of some $\mathrm{CT}$ findings over the years might be attributed to improving $\mathrm{CT}$ image quality but also to increasing experience in the field of paleoradiology. 


\section{CLINICAL RELEVANCE}

- The approach of structured reporting can be transferred to the field of paleoradiology.

- The systematic and standardized identification and assessment of soft tissues in CT are considered the starting point for the detection of possible pathological findings of soft tissues in mummies.

- The scoring system allows quantitative comparison among mummies by means of the total score, but also via the scores of the different subcategories.

Conflict of Interest

The authors declare that they have no conflict of interest.

\section{References}

[1] Harwood-Nash DC. Computed tomography of ancient Egyptian mummies. J Comput Assist Tomogr 1979; 3: 768-773

[2] Zesch S, Panzer S, Rosendahl W et al. From first to latest imaging technology: Revisiting the first mummy investigated with X-ray in 1896 by using dual-source computed tomography. Eur J Radiol Open 2016; 3: $172-181$

[3] Petrella E, Piciucchi S, Feletti F et al. CT Scan of Thirteen Natural Mummies Dating Back to the XVI-XVIII Centuries: An Emerging Tool to Investigate Living Conditions and Diseases in History. PLoS One 2016; 11: doi: e0154349

[4] Panzer S, Gill-Frerking H, Rosendahl W et al. Multidetector CT investigation of the mummy of Rosalia Lombardo (1918-1920). Ann Anat 2013; 195: $401-408$

[5] O’Brien J], Battista J], Romagnoli C et al. CT Imaging of human mummies: A critical review of the literature (1979-2005). Int J Osteoarchaeol 2009; 19: $90-98$

[6] Lynnerup N. Mummies. Yearbk of Phys Anthropol 2007; 50: 162 - 190

[7] Cesarani F, Martina MC, Ferraris A et al. Whole-body three-dimensional multidetector CT of 13 Egyptian human mummies. Am J Roentgenol 2003; 180: 597-606

[8] Hoffman H, Torres WE, Ernst RD. Paleoradiology: Advanced CT in the evaluation of nine Egyptian mummies. RadioGraphics 2002; 22: 377 385

[9] Aufderheide AC (ed) The Scientific Study of Mummies. 1st ed Cambridge: Cambridge University Press; 2003: 287

[10] Panzer S, McCoy MR, Hitzl W et al. Checklist and Scoring System for the Assessment of Soft Tissue Preservation in CT Examinations of Human Mummies. PLoS One 2015; 10: doi:e0133364

[11] Panzer S, Borumandi F, Wanek J et al. "Modeling ancient Egyptian embalming": radiological assessment of experimentally mummified human tissue by CT and MRI. Skeletal Radiol 2013; 42: 1527-1535

[12] Gostner P, Pernter P, Bonatti $G$ et al. New radiological insights into the life and death of the Tyrolean Iceman. J Archaeol Sci 2011; 38: 3425 3431
[13] Rühli F, Chhem R, Böni T. Diagnostic paleoradiology of mummified tissue: interpretation and pitfalls. Can Assoc Radiol J 2004; 5: 218-227

[14] Rühli F. Radiological aspects and interpretation of post mortem artefacts in ancient Egyptian mummies from Swiss collections. Intern J Osteoarcheol 2000; 10: 153-157

[15] Hübener KH, Pahl WM. Computertomografische Untersuchungen an altägyptischen Mumien. Fortschr Röntgenstr 1981; 135: 213-219

[16] Murphy WA Jr, Nedden D zur, Gostner P et al. The iceman: discovery and imaging. Radiology 2003; 226: 614-629

[17] Gostner P, Reinstadler U. Die Kniegelenke des Mannes aus dem Eis. Fortschr Röntgenstr 2004; 176: 1719-1722

[18] Ruff CB, Holt BM, Sládek V et al. Body size, body proportions, and mobility in the Tyrolean "Iceman". J Hum Evol 2006; 51: 91-101

[19] Seiler R, Spielman A, Zink A et al. Oral pathologies of the Neolithic Iceman, c.3.300 BC. Eur J Oral Sci 2013; 121: 137-141

[20] Gostner P, Egarter Vigl E. Report of Radiological-Forensic Findings on the Iceman. J Archaeol Sci 2002; 29: 323-326

[21] Pernter P, Gostner P, Egarter Vigl E et al. Radiologic proof for the Iceman's cause of death (ca. 5.300 BP). J Archaeol Sci 2007; 34: 1784 1786

[22] Maixner F, Krause-Kyora B, Turaev D et al. The 5300-year-old Helicobacter pylori genome of the Iceman. Science 2016; 351: 162-165

[23] Marcovici PA, Taylor GA. Journal Club: Structured radiology reports are more complete and more effective than unstructured reports. Am J Roentgenol 2014; 203: 1265 - 1271

[24] Faggioni L, Coppola F, Ferrari R et al. Usage of structured reporting in radiological practice: results from an Italian online survey. Eur Radiol 2016; [Epub ahead of print] doi:10.1007/s00330-016-4553-6

[25] Larson DB, Towbin A], Pryor RM et al. Improving consistency in radiology reporting through the use of department-wide standardized structured reporting. Radiology 2013; 267: 240-250

[26] Piombino-Mascali D, Jankauskas R, Tamošiūnas A et al. Atherosclerosis in mummified human remains from Vilnius, Lithuania (18th-19th centuries AD): A computed tomographic investigation. Am J Hum Biol 2014; 26: $676-681$

[27] Piombino-Mascali D, Kozakaitė J, Tamošiūnas A et al. Skeletal pathological conditions of Lithuanian mummies. Papers on Anthropology 2014; 23: $118-126$

[28] Panzer S, Tamošiūnas A, Valančius R et al. Radiological evidence of rickets in a Lithuanian child mummy. Fortschr Röntgenstr 2013; 185: 670 672

[29] Panzer S, Piombino-Mascali D, Zink AR. Herniation pits in human mummies: A CT investigation in the Capuchin Catacombs of Palermo Sicily. PLoS One 2012; 7: doi:e36537

[30] Shaw I (ed). The Oxford History of Ancient Egypt. 1st ed. 2000 New York: Oxford University Press, 83

[31] Sydler C, Öhrström L, Rosendahl W et al. CT-Based Assessment of Relative Soft-Tissue Alteration in Different Types of Ancient Mummies. Anat Rec (Hoboken) 2015; 298: $1162-1174$

[32] Panzer S, Zink AR, Piombino-Mascali D. Radiologic evidence of anthropogenic mummification in the Capuchin Catacombs of Palermo, Sicily. RadioGraphics 2010; 30: 1123-1132

[33] Brier B, Wade RS. Surgical Procedures during ancient Egyptian Mummification. Z Ägypt Sprache Alt 1999; 126: 89-97 